\title{
地域在住女性高齢者の開眼片足立ち保持時間と 身体機能との関連
}

\author{
Relationship between One-Leg Standing Time with Eyes Open and \\ Physical Function among Community-Dwelling Elderly Females
}

\begin{tabular}{|c|c|c|}
\hline $\begin{array}{l}\text { 村田 伸 } 1) \\
\text { 豊田 謙二4) }\end{array}$ & $\begin{array}{l}\text { 大山美智江 }{ }^{2)} \\
\text { 藤野 英巳 } 1)\end{array}$ & $\begin{array}{l}\text { 大田尾 浩1) } \\
\text { 弓岡 光徳1) }\end{array}$ \\
\hline
\end{tabular}

SHIN MURATA ${ }^{1)}$, Michie OYAMA ${ }^{2)}$, HiROSHI OTAO ${ }^{1)}$, JUN MURATA ${ }^{3)}$, KENII TOYOTA $^{4)}$, HidEMI FUJINO ${ }^{1)}$, MitSUNORI YUMIOKA ${ }^{1)}$, ISAO TAKEDA ${ }^{1)}$

1) Department of Physical Therapy, Faculty of Health Care Science, Himeji Dokkyo University: 7-2-1 Kamiohno, Himeji-City, Hyogo 670-8524, Japan. TEL +81 079-223-2211

2) Non-Profit Organization NPO Hukusiyogunet

3) Department of Health Sciences, Graduate School of Biomedical Sciences, Nagasaki University

4) Faculty of Human and Social Sciences, Fukuoka Prefecture University

Rigakuryoho Kagaku 23(1): 79-83, 2008. Submitted Jul. 7, 2007. Accepted Sep. 4, 2007.

ABSTRACT: In this study we measured the one-leg standing time with eyes open of 56 elderly community dwelling women and investigated its relationship with upper and lower limb strength and flexibility, sole proprioception? and other physical functions together with attention function. The factors affecting one-leg standing time as indicated by repeated measures regression analysis were foot-gripping strength and age: one-leg standing was more stable at higher foot-gripping strengths and younger ages. These results suggest the importance of increasing foot-gripping strength for improving the one-leg standing ability of elderly community-dwelling females.

Key words: elderly community-dwelling females, one-leg standing time with eyes open, foot gripping force

要旨：本研究は, 地域在住の女性高齢者56名（平均年齢74.8 26.3 歳）の開眼片足立ち保持時間を測定し，上下肢筋力 や柔軟性, 足底感覚などの身体機能評価ならびに注意機能との関連を検討した。重回帰分析によって, 片足立ち保持 時間に影響を及ぼす因子として抽出されたのは，足把持力と年齢であり，足把持力が強いほど，また年齢が若いほど に, 片足立ち保持が安定していることが確認された。今回の知見より, 地域在住女性高齢者の片足立ち能力を高める ためには，足把持力を高めることの重要性が示された。

キーワード：地域在住女性高齢者, 開眼片足立ち保持時間, 足把持力

1) 姫路獨協大学 医療保健学部理学療法学科：兵庫県姫路市上大野7-2-1（テ670-8524） TEL 079-223-2211

2) 特定非営利活動法人NPO福祉用具ネット

3) 長崎大学大学院 医歯薬学総合研究科保健学専攻

4) 福岡県立大学 人間社会学部

\section{受付日 2007年7月7日＼cjkstart受理日２007年9月4日}




\section{I. 研究の背景と目的}

片足立ちの測定は特別な装置を必要とせず，また簡 便に行えるため, とくに, 高齢者の平衡機能検査として 幅広く用いられている1-3)。また, 片足立ち保持能力の 低下が, 高齢者の転倒を引き起こす可能性が報告されて おり4-6), その重要性から, 高齢者の身体機能評価とし て，久くことのできない検査項目となっている。

片足立ち保持能力とその関連要因についての研究は, 高齢者を対象として行われている7-9)。奥住ら ${ }^{7)}$ は, 握力 を高齢者の総合的な筋力として表し, 片足立ち能力との 関連を報告しており, Nagasaki ら ${ }^{8)}$ や笠原ら ${ }^{9)}$ は, 大腿四 頭筋筋力の低下が, 片足立ち動作遂行の阻害因子となる ことを指摘している。また, 横山ら ${ }^{10)}$ は, 健常成人を対 象とした研究から, 足底の感覚と平衡機能との関連を明 らかにしている。しかし, これらの先行研究は, 上肢の 筋力值であったり, 下肢の筋力でも一部の筋力しか対象 としていない。片足立ちに影響を及ぼす要因を検証する ためには, 総合的に身体機能を測定し, 検討する必要が ある。

本研究は, 地域在住女性高齢者を対象に上下肢筀力 や柔軟性, 足底感覚などの身体機能評価ならびに注意機 能に関する検査を行い, 各因子と開眼片足立ち保持時間 との関連を検討した。

\section{II. 対象と方法}

1. 対象

対象は福岡県福智町に居住し，地域のミニデイサー ビス事業に参加している60歳以上の地域在住女性高齢者 で, 重度の認知症が無く（Mini-Mental State Examination が21点以上を対象), 測定データに久損值がなかった56 名（平均年齢 $74.8 \pm 6.3$ 歳, 平均体重 $50.2 \pm 9.8 \mathrm{~kg}$ ) を対象 とした。

ここでのミニデイサービス事業とは, 隣保館高齢者 交流事業に位置づけられ, 住民の自主性に任せた活動 (参加者相互の情報交換や食事など) を毎月1回の頻度で 4時間程度行われている。

対象者の募集は, 町内会報による募集のみならず，ミ ニデイサービス事業を担当している役場職員や社会福 祉協議会職員, および地域の高齢者リーダーから積極的 に参加を呼びかけてもらう, いわゆるプロアクティブな 募集 ${ }^{11}$ が行われた。対象者には, 研究の趣旨と内容につ いてロ答と書面で説明し，同意を得て研究を開始した。 なお, 調查は地域内の公民館あるいは役場併設の体育館
で実施したが，対象者は自家用車や自転車，あるいは徒 歩によって自ら調查に参加できる高齢者であった。

\section{2. 測定方法}

片足立ち保持時間の測定は，開眼片足立ち位で姿勢 保持できる時間について，120秒を上限としてデジタル ストップウォッチを用いて測定した。この際, 被験者に は裸足になること, 両上肢はかるく体側につけること, $2 \mathrm{~m}$ 前方の視線と同じ高さの点を注視することを条件に 測定した。

上下肢の筋力として握力, 大腿四頭筋筋力, 足把持力 を測定した。

握力の測定は，デジタル式握力計（竹井機器工業製） を用いて, 立位で左右の上肢を体側に垂らした状態で測 定した。

大腿四頭筋筋力は，ハンドヘルドダイナモメーター （アニマ社製等尺性筋力測定装置 $\mu$ Tas F-1）を用い，被 験者を坐位, 膝関節 90 度屈曲位として, その最大筋力を 測定した。

足把持力は, 被験者に端座位をとらせ, 膝関節を 90 度 屈曲した姿勢で足把持力測定器を用いて測定した。な お, この測定器から得られる測定值の再現性について は, 級内相関係数が 0.953 という高い再現性を確認して いる12)

足底感覚検查はSemmes-Weinstein Monofilamentsを用い たタッチテスト法により，第1足指先端部の触圧覚閾值 を測定した。Semmes-Weinstein Monofilamentsを用いた感 覚検査は, その信頼性と妥当性が確認され, 広く応用さ れている13,14)。タッチテストでは，20種類の異なる直径 のfilamentを皮膚に1秒間押し当て, 感知可能なfilament直 径の最小值を触圧覚閾值データとして採用した。各 filamentから皮膚に加えられる負荷量はそれぞれ $\log _{10} \mathrm{mg}$ で表される。また，タッチテストはfilament毎に同一部 位で3回実施され, 3回の刺激全てを感知できた場合を合 格とした。

柔軟性は, 長座位体前屈距離をデジタル式長座体前 屈測定器（竹井機器工業製）を用いて評価した。

注意機能の評価には, Trail making test-Part B (TMT-B) を用いた。TMT-Bは元来Army individual test battery (1944) に含まれていたもので，主に注意の選択機能を視覚的 に評価する尺度として広く用いられ ${ }^{15}$, 注意機能の机 上検査法としての信頼性と妥当性がすでに確認されて いる16-19)。TMT-Bの実施方法は, 紙面上にランダムに配 置された1から13までの数字と「あ」から「し」までの

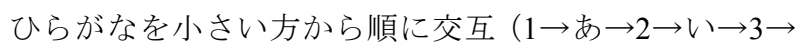


表1 各項目の測定結果 $(\mathrm{n}=56)$

\begin{tabular}{lrc}
\hline & 平均值 & 標準偏差 \\
\hline 片足立ち保持時間 $($ 秒) & 29.6 & 21.7 \\
握力 $(\mathrm{kg})$ & 19.3 & 4.6 \\
大腿四頭筋筋力 $(\mathrm{kg})$ & 15.4 & 6.2 \\
足把持力 $(\mathrm{kg})$ & 4.9 & 2.1 \\
柔軟性 $(\mathrm{cm})$ & 34.5 & 7.3 \\
足底感覚 $(\mathrm{g})$ & 4.2 & 0.4 \\
注意機能 $($ 秒 $)$ & 211.1 & 86.6 \\
\hline
\end{tabular}

う）に線で結んでいく。評価はスタートから順にすべ てを結ぶまでの時間を測定し，その所要時間を指標と した。

なお, 測定肢はすべて右上下肢であり, 足底感覚と注 意機能以外の測定はすべて2回測定し, その最大值を採 用した。足底感覚と注意機能は測定值が小さいほど良好 な状態を示すが, その他の測定值は数值が大きいほど高 い身体能力であることを示す。

統計処理は, 被験者56名の片足立ち保持時間と他の測 定值との関係について, ピアソンの相関係数を用いて検 討した。さらに, 目的変数を片足立ち保持時間, 説明変 数を年齢, 握力, 大腿四頭筋筇力, 足把持力, 足底感 覚, 柔軟性, 注意機能とした重回帰分析のステップワイ ズ法 (変数減少法) を用いて, 片足立ち保持時間に影響 を及ぼす因子を抽出した。

なお，統計解析にはStatView5.0を用い，有意水準を5 \%とした。

\section{III. 結 果}

表1に被験者56名の各測定項目の平均值と標準偏差,
表2に各測定值間の単相関分析を示した。片足立ち保持 時間と有意な相関を示したのは, 相関係数が高い順に足 把持力, 年齢, 注意機能, 大腿四頭筋筋力, 握力であ り，柔軟性と足底感覚とは有意な相関を認めなかった (表2)。

ステップワイズ重回帰分析 (変数減少法)により, 片 足立ち保持時間に影響を及ぼす因子として抽出された 項目は，足把持力と年齢の2項目であり，標準偏回帰係 数は順に $0.55,-0.25$ あっあた。

重回帰分析によって採用された足把持力と年齢の $2 つ$ の変数より作成される重回帰式は，「片足立ち保持時間 $=87.91+(8.71 \times$ 足把持力 $)-(1.35 \times$ 年齢 $) 」$ であり この重回帰式の決定係数 $\left(\mathrm{R}^{2}\right)$ は $0.47 て ゙$ 有意であった $(p<0.01)$ 。これは足把持力が強いほど, 年齢が若いほど に, 片足立ちで保持できる時間が長いことを示している。

\section{IV. 考 察}

本研究では，高齢者の片足立ち保持時間に影響を及 ぼすことが考えられる年齢, 上下肢筋力（握力, 大腿四 頭筋筋力, 足把持力), 足底感覚, 柔軟性, 注意機能を 測定し,それぞれの因子と片足立ち保持時間との関連を 検討した。

本研究における単相関分析の結果, 片足立ち保持時 間と有意な相関が認められたのは，年齢，握力，大腿四 頭筇筋力, 足把持力, 注意機能の5項目であった。片足 立ち保持能力と上下肢筋力との関連については, すでに 先行研究7-9) で報告されており, 本結果も先行研究を追 認した。なかでも，足把持力との相関係数は，測定した 項目のなかで最も高かった。足把持力とは，地面を足 趾・足底で掴む力であり, 短母趾屈筋, 長母趾屈筋, 虫 様筋, 短趾屈筋, 長趾屈筋などの作用により起こる複合

表2 各変数間の単相関分析 $(n=56)$

\begin{tabular}{|c|c|c|c|c|c|c|c|}
\hline & $\begin{array}{c}\text { 片足立 } \\
\text { 保持時間 }\end{array}$ & 年齢 & 握力 & 柔軟性 & 足把持力 & 四頭筋筋力 & 足底感覚 \\
\hline 年齢 & $-0.45^{* *}$ & & & & & & \\
\hline 握力 & $0.27 *$ & -0.11 & & & & & \\
\hline 柔軟性 & -0.12 & -0.09 & 0.21 & & & & \\
\hline 足把持力 & $0.61 * *$ & -0.22 & $0.54 * *$ & 0.21 & & & \\
\hline 四頭筋筋力 & $0.38 * *$ & -0.15 & $0.51 * *$ & 0.24 & $0.53 * *$ & & \\
\hline 足底感覚 & -0.21 & $0.41 * *$ & -0.15 & -0.17 & $-0.28^{*}$ & -0.09 & \\
\hline 注意機能 & $-0.45 * *$ & $0.42 * *$ & 0.05 & -0.20 & -0.13 & -0.16 & 0.21 \\
\hline
\end{tabular}

$* * p<0.01, \quad * p<0.05$ 
運動である 20$)$ 筆者ら ${ }^{21)}$ は, 健常成人女性を対象に, 片 足立ち位での重心動摇に影響を及ぼす因子について, 重 回帰分析などによって検討した結果, 足把持力が最も影 響する因子であることを見出しており,このことについ ても矛盾しない。

その他, 年齢は低いほど, 注意機能は高いほどに片足 立ち保持時間が長いことが見出された。筆者ら ${ }^{22)}$ は先行 して, 地域在住の後期高齢者（75歳以上）85名の身体機 能を調查し, 前期高齢者（65～74歳）96名と比較した結 果, 加齢に伴い片足立ち保持時間の短縮が著明に認めら れることを明らかにしている。また, 注意機能との関連 が指摘されているdual- task ${ }^{23)}$ 下における活動中の身体動 摇が増大するという報告が散見される24,25)。本結果も先 行研究と矛盾しない結果であった。

一方, 柔軟性と足底感覚について, 片足立ち保持時間 との間に有意な相関は認められなかった。本研究におけ る柔軟性は, 長座体前屈距離を指標としたが, 長座体前 屈の測定は, Curetonが1941年に水泳選手の基礎的身体 能力の指標として用いられたことより始まる26)。さら に, 1970年代に入り, 日本を含めた世界各国に普及した テスト法である26)。しかし, 近年の報告では, 長座体前 屈の測定は, 上下肢の長さや足部の固定などにより影響 を受けやすいことや, 長座体前屈と歩行速度などの運動 能力とは, 相関関係が認められないなどの問題点が指摘

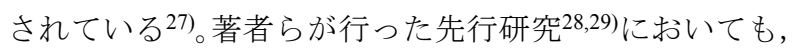
在宅高齢者の長座体前屈距離と他の身体能力值との関 連は乏しい。また, 本結果においても長座体前屈距離 は, 片足立ち保持時間のみならず, すべての測定值と相 関が認められなかった。これらのことから, 本研究で用 いた長座体前屈距離の測定は, 高齢者の身体能力を評価 する項目としては適切でないのかもしれない。

従来から, 足底感覚と片足立ち保持時間との関連に ついては, 健常成人を対象に検討されてきた。横山ら 10) や浅井ら ${ }^{30)}$ は足部を冷却し, 足底の感覚情報入力を減少 させることにより, 立位での重心動摇が有意に増大した と報告している。また, 片平ら ${ }^{31}$ は足底部の皮膚感覚に ついて, 姿勢の安定度が低い状態では皮膚感覚の情報の

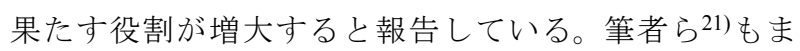
た, 健常成人女性における片足立ち位での重心動摇に影 響を及ぼす要因の一つが, 足底感覚であることを見出し ている。しかしながら, 本研究では足底感覚と片足立ち 保持時間との関連は認められず, 先行研究と矛盾する結 果となった。この理由について本研究では明らかにでき ないが,つぎの理由を推察した。本研究と先行研究との 相違点は, その研究対象者が先行研究では健常成人であ
るのに対して, 本研究では高齢者を対象としたことであ る。若年者に比べ高齢者では, 開眼と閉眼における片足 立ち保持能力の差が大きいことは周知の事実である。こ のことから, 若年者では足底からの感覚情報を効果的に 姿勢制御に使用しているが, 高齢者の場合, 足底からの 感覚情報のみでは, 片足立ちを保持するための情報が不 足していることが考えられる。とくに高需者では, 足底 の感覚情報よりも視覚からの情報を優位に姿勢制御に 使用しているのかもしれない。

さらに，各項目間の交絡関係を調節した重回帰分析 によって, 片足立ち保持時間に独立して影響を及ぼす因 子として抽出されたのは, 足把持力と年齢の 2 項目であ り, 足把持力は強いほど, 年齢は若いほどに片足立ちが 安定しているという関係が認められた。単相関分析に よって, 片足立ち保持時間と有意な関連が認められた握 力, 大腿四頭筋筋力, 注意機能の3 項目は, 交絡関係を 調節した重回帰分析では有意ではなかった。上下肢筋力 の指標とした握力, 大腿四頭筋筋力, 足把持力の内部相 関係数はそれぞれ $0.5 を$ 超えており，今回測定した説明 変数間の単相関分析の中で最も高い相関を示した。これ は大腿四頭筋筋力や握力が強いほど足把持力も強いこ とを示し,このことが単変量の解析での見かけ上の関連 につながったと考えられる。同様に, 注意機能と年齢と の間にも有意な相関が認められるため, 注意機能が重回 帰分析における片足立ち保持時間の関連要因として抽 出されなかったものと推察した。

これらの知見より, 地域在住の女性高齢者では, 上下 肢筋力の代表值として頻繁に用いられる握力や大腿四 頭筋筋力よりも，足把持力の方が，片足立ち保持時間に 影響を与えていることが示唆された。すなわち, 地域在 住女性高齢者の片足立ち能力を高めるためには, 上下肢 の主要筇力を強化するよりも, 足把持力をトレーニング することの重要性が示唆された。

\section{引用文献}

1) Drusini AG, Eleazer GP, Caiazzo M, et al.: One-leg standing balance and functional status in an elderly community-dwelling population in northeast Italy. Aging Clin Exp Res, 2002, 14(1): 4246.

2) 種田行男: 姿勢調節の加齢変化. PTジャーナル, 1996, 30(5): 305-310.

3) 内山 靖, 山端るり子, 榎本香織・他 : 平衡機能. PTジャー ナル， 1998, 32(12): 949-959.

4) de Rekeneire N, Visser M, Peila R, et al.: Is a fall just a fall: correlates of falling in healthy older persons. The health, aging and body composition study. J Am Geriatr Soc, 2003, 51(6): 841-846. 
5) Haga H, Shibata H, Shichita K, et al.: Falls in the institutionalized elderly in Japan. Arch Gerontol Geriatr, 1986, 5(1): 1-9.

6) 島田裕之, 内山 靖, 加倉井周一: 21 力月間の縦断研究によ る虚弱高齢者の転倒頻度と身体機能変化との関係. 総合リ 八, 2002, 30(10): 935-941.

7) 奥住秀之, 古名丈人, 西澤 哲・他 : 静的平衡機能と筋力と の関連一高齢者を対象とした検討. Equilibrium Res, 2000, 59: 574-578.

8) Nagasaki H, Itoh H, Furuna T: A physical fitness model of older adults. Aging, 1995, 7(5): 392-39.

9) 笠原美千代, 山崎裕司, 青木詩子 - 他 : 高齢者における片脚 立位時間と膝伸展筋力の関係. 体力科学, 2001, 50(3): 369-374.

10) 横山茂樹, 高柳公司, 松坂誠鷹・他: 足底部感覚情報が立位 姿勢調整および歩行運動に及ぼす影響. 理学療法学, 1995, 22(3): 125-128.

11) 大山美智江, 豊田謙二 : 「住民が創る健康・福祉のまち/ほ うじょう」再生計画 (事業報告) 。福岡県立大学付属研究所 生涯福祉研究センター研究報告叢書, 2007, 28: 1-41.

12) 村田 伸, 甲斐義浩, 田中真一・他: ひずみゲージを用いた 足把持力測定器の開発. 理学療法科学, 2006, 21(4): 363-367.

13) Cole KJ, Rotella DL, Harper JG: Tactile impairments cannot explain the effect of age on a grasp and lift task. Exp Brain Res, 1998, 121(3): 263-269.

14) Melchior H, Vatine JJ, Weiss PL: Is there a relationship between light touch-pressure sensation and functional hand ability? Disabil Rehabil, 2007, 29(7): 567-575.

15) 鹿島晴雄, 半田貴士, 加藤元一郎 - 他 : 注意障害と前頭葉損 傷. 神経進歩, 1986, 30(5): 847-858.

16) Lezak MD: Neuropsychological Assessment Third Edition. Oxford University Press, New York, 1995, pp381-384.

17) Heilbronner RL, Henry GK, Buck P, et al.: Lateralized brain damage and performance on trail making A and B, Digit Span Forward and Backward, and TPT Memory and Location. Arch Clin Neuropsychol, 1991, 6(4): 251-258.

18) Tombaugh TN: Trail Making Test A and B: normative data stratified by age and education. Arch Clin Neuropsychol, 2004, 19(2): 203-214.
19) Amodio P, Wenin H, Del Piccolo F, et al.: Variability of trail making test, symbol digit test and line trait test in normal people. A normative study taking into account age-dependent decline and sociobiological variables. Aging Clin Exp Res, 2002, 14(2): 117131.

20) 村田 伸, 忽那龍雄 : 足把持力測定の試み一測定器の作成と 測定值の再現性の検討. 理学療法科学, 2002, 17(4): 243-247.

21) 村田 伸: 開眼片足立ち位での重心動摇と足部機能との関連 一健常女性を対象とした検討. 理学療法科学, 2004, 19(3): 245-249.

22) 村田 伸, 大山美智江, 大田尾浩 - 他 : 地域在住高齢者の身 体・認知 - 心理機能に関寸る研究一前期高齢者之後期高齢者 の比較. 健康支援, 2007, 9(2): 110-118.

23) Woollacott M, Shumway-Cook A: Attention and the control of posture and gait: a review of an emerging area of research. Gait Posture, 2002, 16(1): 1-14.

24) 村田 伸, 津田 彰, 中原弘量 : 音楽聴取と精神作業負荷が 重心動摇に及ぼす影響. 理学療法科学, 2005, 20(3): 213-217.

25) 山田 実, 平田総一郎, 小野 玲: 変形性股関節症患者は dual-task下での歩行時に体幹動摇が増大寸る. PTジャーナ ル, 2006, 40(11): 933-937.

26) 波多野義郎：立位体前屈から長座体前屈一. 体育の科学, 1997, 47: 884-888.

27) 諸橋 勇: 高齢者の柔軟性と理学療法. 理学療法, 1999, 16(9): 718-724.

28) 村田 伸, 熊谷秋三, 津田 彰: 足部柔軟性の再現性と妥当 性に関寸る研究一健常成人と障害高齢者における検討. 健康 科学, 2005, 27: 49-55.

29) 村田 伸, 津田 彰, 稲谷ふみ枝・他 : 在宅障害高齢者の転 倒に影響を及ぼす身体及び認知的要因. 理学療法学, 2005, 32(2): 88-95.

30) 浅井 仁, 奈良 勲, 立野勝彦・他 : 極低温空気による足底 冷却が安静時立位姿勢調節及び有効支持基底面の広さに及 ぼす影響. 理学療法学, 1991, 18(1): 19-25.

31) 片平清昭 : 立位姿勢における身体動摇と足底部位圧. 姿勢研 究, 1987, 7(1): 7-12. 